\title{
THE EFFECT OF THE CONDUCTIVE LAYER ON THE THERMAL PROPERTIES OF DAMAGED ORBITER TPS PANEL
}

\begin{abstract}
The content of the article concerns the analysis of heat insulating material of the thermal protection system, which is related to aerodynamic heating during atmospheric reentry by spacecraft. The example of the heat flux distribution as a function of flight time for analysis is used. The purpose of the article is to investigate the effect on the results of the new material of model with relatively high thermal conductivity coefficient across the isolating tile. It is considered that it may allow to compensate the temperature on the surface of underlying structure. The article contains the comparison of two types of thermal analysis of selected insulating tile models. The first case assumed that the models contain only three layers, e.g. insulation, strain isolator pad and underlying structure. In the second analysis, calculations are based on models consisting of four layers. Due to the good thermal properties as the additional material titanium alloy is selected. All analyses take into account two types of models: undamaged and damaged tiles. The conclusions contain graphs of maximum temperature distribution in function of time on the surfaces of selected layers. The results allowed to determine the temperature difference calculated on the basis of the considered of both cases.
\end{abstract}

Key words: aerodynamic heating, unsteady heat flow, heat protection

\section{Introduction}

During atmospheric reentry of the spacecraft comes to the so-called aerodynamic heating. This phenomenon is due to the enormous friction surface of the vehicle with air. Such friction occurs as the vehicle moves at hypersonic speed [2]. Aerodynamic heating is related with high vehicle temperatures. They not exceed $150^{\circ} \mathrm{C}$. Therefore, all the vehicles carrying out orbital and interplanetary missions without adequate heat shield would burn during atmospheric are so high that they may cause the melting of steel. Vehicles skins such as

\footnotetext{
${ }^{1}$ Autor do korespondencji/corresponding author: Łukasz Brodzik, Politechnika Poznańska, adres: Pl. Marii Skłodowskiej-Curie 5, 60-965 Poznań, tel: 61665 2779, e-mail: lu- 
Space Shuttle are made of aluminium alloy, where the temperature usually does reentry.

In the paper is considered insulation, one of type of heat shield. Insulations are intended to reduce heat flow in the direction of the skin. Excess of heat is discharged to the environment by radiation [4]. Insulating tiles was used in the space shuttles. The biggest heat loads were carried by HRSI (High-Temperature Reusable Surface Insulation) tiles and this type of tiles was taken to analysis. HRSI tiles are made from a material called LI900. Tiles are bonded to the SIP (Strain Isolator Pad) with RTV (Room-Temperature Vulcanized) silicone adhesive, before bonding directly to the aluminium skin [3]. Such a connection provides a reduction in the risk of exceeding the limit of stress in the insulation. The tile from the outside is surrounded by a coating layer RCG (Reaction-Cured Glass), thanks to which it has a characteristic black color.

In the space around the Earth, there are two main sources of heat shield damage as a result of the collision. These are micrometeoroids and space debris which is a result of human activities in space. Infringement of isolation structures can have serious consequences during atmospheric reentry. Lost tile causes a risk of loss of neighboring tiles. Insulation faults appeared during the history of Shuttle flights. Of course, this risk also involves other space vehicles and all technical facilities, such as the International Space Station. The issue of heat shields damage is difficult to solve because even small objects like micrometeoroids can seriously damage the structure of the material. The reason for that is high speed moving objects in space, ranges from 6 to $16 \mathrm{~km} / \mathrm{s}$ [10]. In addition, there is the increase of orbit debris resulting from human activities. From these reasons researching issues of heat conduction of damaged insulation is the subject of this article.

\section{Formulation of the heat transfer problem}

Two-dimensional model was used for the numerical simulation. The first model consists of three layers. The first one was the insulation from Li900, the second one strain isolator pad made from Nomex and the last one aluminum alloy as very thin strip. RCG and RTV layers were omitted. The second full model has one more layer made of titanium alloy. For the assumed model the insulation thickness equals $85 \mathrm{~mm}$. Axisymmetric model was created based on real dimensions of the insulating tile. A model of damage was made for the case where the defect in insulation is formed by an impact with small object moving at a hypersonic speed [9]. This shape and simplification is given in figure 1 .

Material properties for LI900, Nomex and titanium alloy 6AL4V are based on the literature [11]. The tile is heated with variable intensity. This intensity for time from 0 at entering atmosphere to 8000 seconds, long after landing is given by an example from literature [7]. Such a long time is condition to find out 
where is the peak of the temperature on the underlying structure (lower surface of SIP). External surfaces of the model are perfectly isolated. Therefore the heat is transported from insulation and is given back in the same way. It gives the worst situation because of the highest temperatures. In reality the heat flux in the tile is transported by radiation, conduction and convection. It is caused by appearance of the air inside the tile.
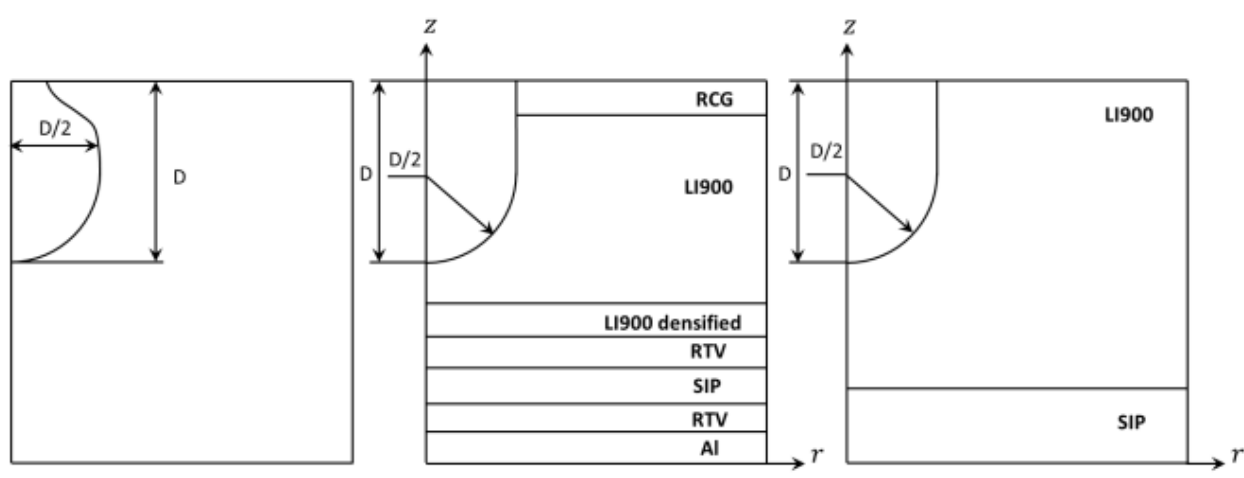

Fig. 1. The geometry model: on the left - the real model, in the middle - simplification, on the right - numbering walls.

Analysis of heat transportation is fairly well understood. Therefore in the numerical calculation an easier method is applied. It is assumed that there is only conduction in tile. This conduction is a function of temperature and pressure. Pressure changes in time and is dependent on altitude. At the beginning of reentry pressure is very small. It is caused by the occurrence of conditions similar to the vacuum. After reaching 2100 seconds pressure is stabilized and equals about $1015 \mathrm{hPa}$. Pressure as a function of time was taken to the analysis from the literature [8]. For heat loading with variable intensity in time causes that the analysis has non-stationary conditions. Conduction for the axisymmetric model in the cylindrical coordinate system is expressed by the equation:

$$
\rho c_{p}\left(\frac{\partial T}{\partial t}\right)=\frac{1}{r} \frac{\partial}{\partial r}\left(k_{r} r \frac{\partial T}{\partial r}\right)+\frac{\partial}{\partial z}\left(k_{z} \frac{\partial T}{\partial z}\right)
$$

where: $\rho$ - density, $c_{p}$ - specific heat for constant pressure, $k$ - thermal conductivity, $\mathrm{T}$ - temperature

The heat is radiated from insulation. RCG layer provides good thermal properties at higher temperatures. Thus, undamaged part of the tile has constant emissivity equals 0.85 . When the tile is damaged radiation has more difficult nature. In a cavity some particles leave insulation. Others collide with walls of this cavity. Therefore in some places the temperature increases. To obtain tem- 
perature distribution around the cavity radiative transfer equation RTE should be solved. This equation for an absorbing, emitting, and scattering medium at position $\vec{R}$ in the direction $\vec{s}$ is as follows $[1,8]$ :

$$
\frac{d I(\vec{R}, \vec{s})}{d s}=-\beta I(\vec{R}, \vec{s})+\kappa_{a} n^{2} \frac{\sigma T^{4}}{\pi}+\frac{\kappa_{s}}{4 \pi} \int_{0}^{4 \pi} I(\vec{R}, \vec{s}) P\left(\vec{R}, \overrightarrow{R^{\prime}}\right) d R^{\prime}
$$

where: $I(\vec{R}, \vec{s})$ - the intensity of radiation, $\beta$ - extinction coefficient, $\kappa_{a}$ - absorption coefficient, $\kappa_{s}$ - scattering coefficient, $n$ - refractive index, $\sigma$ - Stefan Boltzmann constant, $P\left(\vec{R}, \overrightarrow{R^{\prime}}\right)$ - the phase function.

There are different models of approximation solutions of this equation. In the analysis diffusion approximation was used. To keep proper behaviour of insulation during the simulation in damaged place emissivity is in function of temperature. This property was taken from the literature [6]. Calculations were carried out in FreeFem++. This numerical code uses Finite Element Method [5]. Models are built average from 2000 triangular elements. The model of damaged tile is defined by two domains. First one relates to the tile and second one to the cavity with air. The dimension of the cavity D equals $4 \mathrm{~cm}$.

\section{Results and discussion}

Based on the theoretical and analytical considerations described previously, computer codes have been developed to simulate axisymmetric heat transfer problem. All simulations were performed with precision of $1^{\circ} \mathrm{C}$ and with max iterations equal to 8 . To reduce temperature in the underlying structure titanium alloy was used. Conduction takes place in this case in two directions: in the plane and through a tile. The plate made of titanium alloy was placed in a tile on two levels.

There are four models: undamaged and damaged tile with titanium and without titanium. Solutions are presented in Figures 2-6. Figure 2 shows maximum temperatures on the insulation surface. During flight, when aerodynamic heating occurs, temperature in insulation intensively increases. Maximum value appears after 850 seconds. Insertion plate made of titanium almost does not change temperatures. An extensive damage in the tile results in huge peak of temperature. For undamaged tile maximum temperature equals $982^{\circ} \mathrm{C}$ and for damaged tile $1935^{\circ} \mathrm{C}$. Damaged tile with titanium plate which is placed higher has different temperatures compared with the same tile without titanium, mainly after 2000 seconds. At the time of 3315 seconds this difference is the biggest and equals $84^{\circ} \mathrm{C}$. It causes that the plate accumulates locally heat due to its 
movement in the transverse direction. Later temperature stabilizes and at 8000 seconds the difference between damaged and undamaged tiles equals $170^{\circ} \mathrm{C}$.

Two next measurements were made at the height of 40 and $15 \mathrm{~mm}$ in the tile. At the height of $40 \mathrm{~mm}$ for damaged tile the biggest differences are for the tile with titanium plate which is higher. The reason of that is the same accumulation of the heat as before. Maximum temperature is above $1600^{\circ} \mathrm{C}$. After 2100 seconds differences between every models of damaged tile are approximately $30^{\circ} \mathrm{C}$ and at 8000 seconds temperature decreases below $300^{\circ} \mathrm{C}$. Curves of temperatures for models of undamaged tile with titanium placed lower and without titanium are almost the same. The same as in damaged tile model for titanium placed higher in undamaged tile model temperature has a lower maximum and it equals $252^{\circ} \mathrm{C}$. For titanium placed lower this peak is $92^{\circ} \mathrm{C}$ higher. After exceeding 8000 seconds temperature is similar and equals approximately $108^{\circ} \mathrm{C}$. Measurements at the height of $15 \mathrm{~mm}$ show that temperature is much lower. For damaged tile this difference is equal to around $1000^{\circ} \mathrm{C}$. After exceeding 2655 seconds temperature decreases exponentially. At this time damaged tile model with titanium placed lower has lower maximum. This maximum equals $373^{\circ} \mathrm{C}$. Although temperatures are noticeably lower, temperature drop is smaller than in the model without titanium. Temperature curves for models of undamaged tile shows visible influence of titanium in both cases. Although temperatures after 8000 seconds are very similar the maximum for undamaged tile without titanium is about $39^{\circ} \mathrm{C}$ higher and equals to $178^{\circ} \mathrm{C}$. For this height, peaks of temperature take place later than before. It causes that the heat needs time to move deeper in the tile.

Last measurements were made in SIP. The inner surface is from the insulation side. In both cases curves representing maximum temperatures are very similar. This is the result of that the thickness of Nomex is small and equals approximately $5 \mathrm{~mm}$. For instant in damaged tile model on the inner surface peak temperature is reached after 3915 seconds and equals $425^{\circ} \mathrm{C}$. On the outer surface maximum temperature appears 240 seconds later and decreases by $1^{\circ} \mathrm{C}$. Thus discussion of the results in this part of the tile is limited only to the inner surface. In both cases of damaged tile titanium alloy has significant influence on the peak temperature. However, the lowest temperature is when the plate of titanium is situated at $15 \mathrm{~mm}$. When titanium is lower the maximum temperature equals $342^{\circ} \mathrm{C}$ and when is higher $400^{\circ} \mathrm{C}$. In undamaged tile without titanium after 5235 seconds appears maximum temperature and equals $163^{\circ} \mathrm{C}$. Presence of titanium causes decreasing temperature to $138^{\circ} \mathrm{C}$ (1405 seconds later) and $131^{\circ} \mathrm{C}$ (725 seconds later). Temperatures in insulations have large values. LI900 material can operate until $1260^{\circ} \mathrm{C}$. Temperatures in solution are much greater, even greater than for melting point which is equal to $1704^{\circ} \mathrm{C}$. Photons bombard surface of damage and heat is accumulated in the cavity. This huge heat flux will cause disappearance of the part of insulation in reality. 


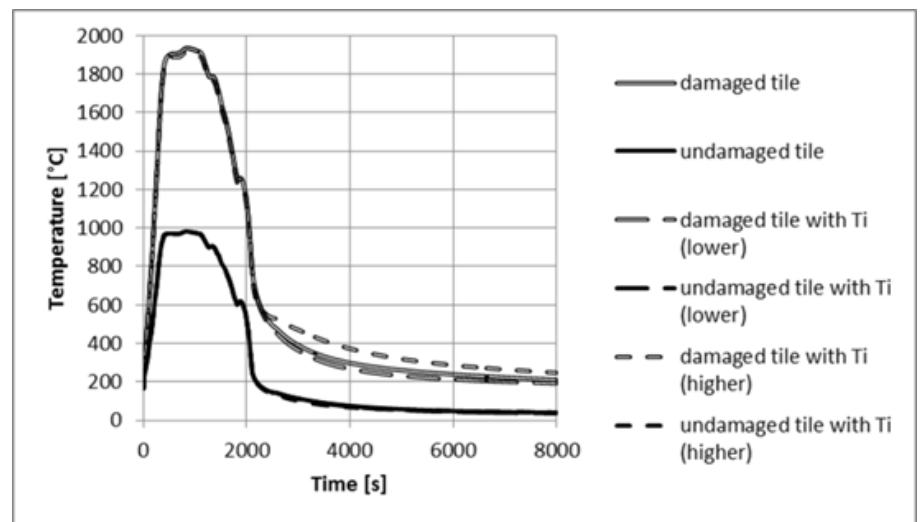

Fig. 2. Maximum temperature on the insulation surface.

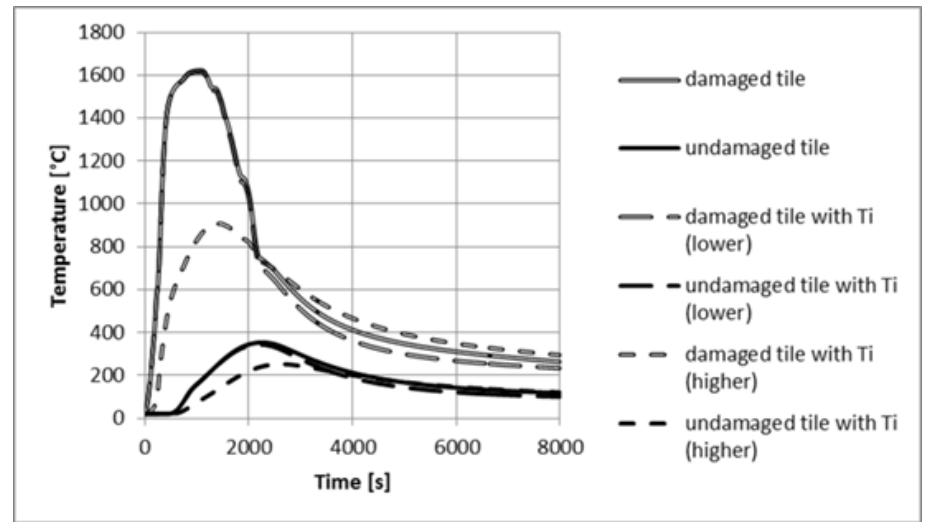

Fig. 3. Maximum temperature at the height of $40 \mathrm{~mm}$.

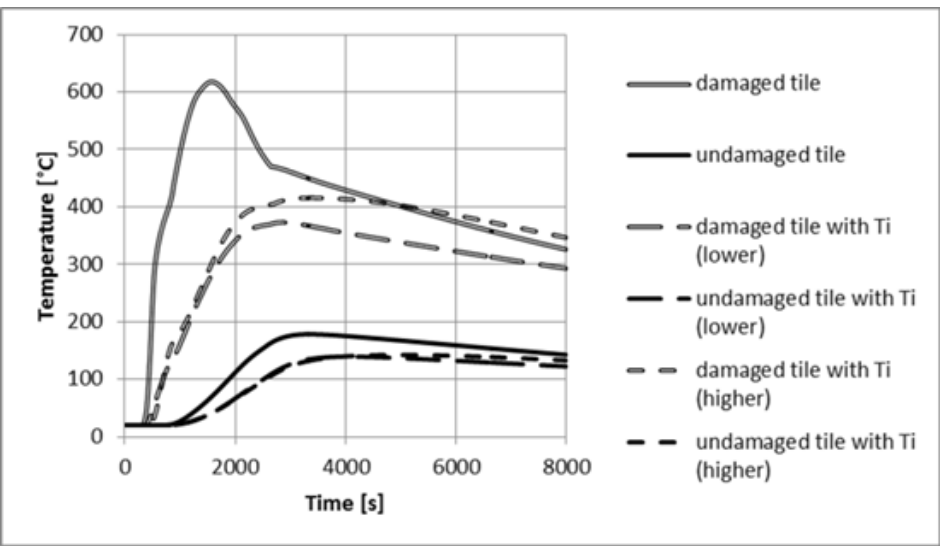

Fig. 4. Maximum temperature at the height of $15 \mathrm{~mm}$. 


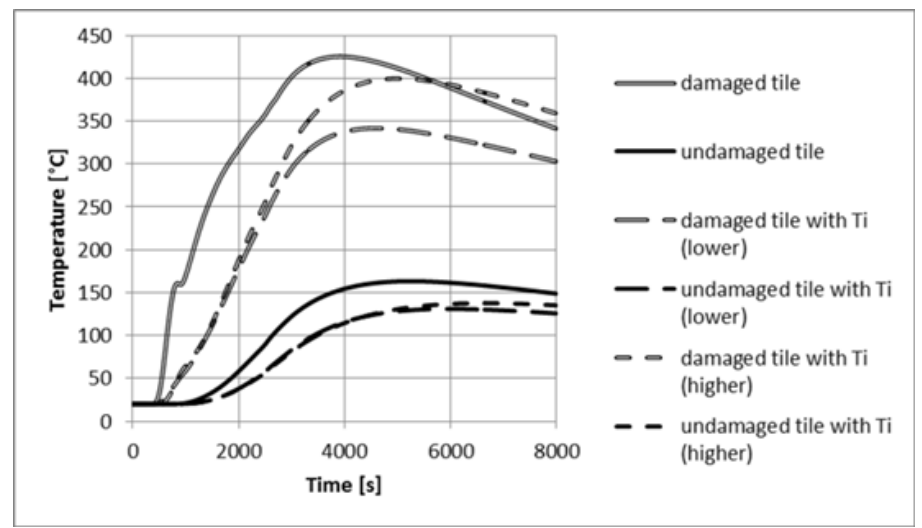

Fig. 5. Maximum temperature on the inner surface of SIP.

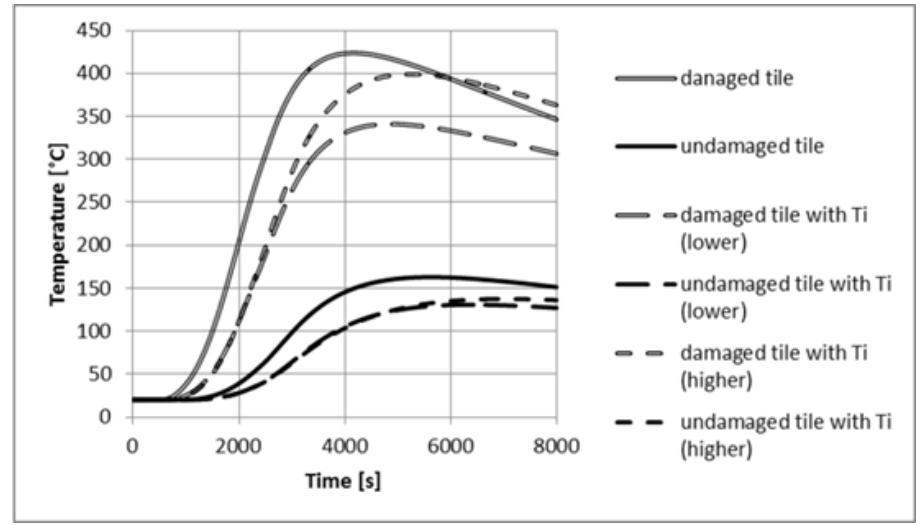

Fig. 6. Maximum temperature on the outer surface of SIP.

\section{Conclusions}

In this paper a new solution is presented for the heat transfer. When the tile is heated titanium presence causes that the temperature on the surface of underlying structure decreases. In SIP the temperature decreases about $32^{\circ} \mathrm{C}$. The temperatures simultaneously in cavity have very similar values. This is very important advantage, because the surface of damage does not have to carry the additional heat loads. It is invaluable because of the possibility of large damage occurrence. The solution shows that heated surface cools down longer. The heat is accumulated inside the insulation and there can be observed the increase of a temperature. Titanium alloy after heating can destroy the tile. This insulating material is fragile and has low resistance to loading more tension. Therefore this analysis was used only for verification of the idea about possibility of the tem- 
perature reduction on the surface of spaceship skin often built from aluminium alloy. After landing damaged skin is more problematic as damaged tile. This idea can be developed in the future. For these tests the additional material with particular characteristics should be chosen. These characteristics include: relatively high operating maximum temperature, heat capacity and good thermal conductivity in transverse direction. Second important issue is using the material which does not cause crack of the insulation and isolator pad. This means that this material should provide proper thermal expansion coefficient.

\section{References}

[1] Byun D., Lee C., Baek W. S.: Radiative heat transfer in discretely heated irregular geometry with an absorbing, emitting, and anisortopically scattering medium using combined Monte-Carlo and finite volume method, Int. J. Heat Mass Transfer 47 (2004) 4195-4203.

[2] Daken H.H.: Simulating the Aerodynamic Heating of Gun-Lauched Projectiles in hypersonic Applications, $13^{\text {th }}$ Int. Conf. Aerospace Sciences \& Aviation Technology, Cairo 2009 pp. 1-16.

[3] Dobrowski A. D., Rowe J.: "Comand" analysis of the shuttle orbiter thermal protection system tiles, Conf. Finite Element Methods and Technology, Paper No. 15, pp. 2, 1981.

[4] Entry thermal protection, National Aeronautics and Space Administration SP-8014, Washington 1968.

[5] Hecht F., FreeFem++, Manual, Third edition 3.11, Paris 2011.

[6] Ng H. W., Friedmann P. P., Waas M. A.: Thermomechanical analysis of a thermal protection system with defects and heat shorts, 47th AIAA/ASME/ASCE/AHS/ASC Structures, Structural Dynamics, and Materials Conf., Newport 2006, pp. 13-23.

[7] Mayers D. E., Martin J. C., Blosser L. M.: Parametric weight comparison of advanced metallic, ceramic tile, and ceramic blanket thermal protection systems, National Aeronautics and Space Administration Technical Memorandum 210289, pp. 12, Hampton 2000.

[8] [8] Modest F. M.: Radiative heat transfer, Second edition, Academic Press, Amsterdam 2003.

[9] O'Connor B.: Technical Material (Chapter 4). Topics in Handbook for limiting orbital debris, National Aeronautics and Space Administration - Handbook 8719.14, pp. 134-149, Washington 2008.

[10] Williams D. S., Curry M. D.: Thermal protection materials: thermophysical property data, National Aeronautics and Space Administration - Reference Publication 1289, pp.15-19, Houston 1992.

[11] Peterson E. G., Lynch K. D.: Micrometeoroid and Orbital Debris Environments for the International Space Station, The Aerospace Corporation: El Segundo 2007. 


\section{WPŁYW WARSTWY PRZEWODZACEJ NA WŁAŚCIWOŚCI TERMICZNE USZKODZONEJ PŁYTKI SYSTEMU OSŁONY TERMICZNEJ ORBITERA}

\section{Streszczenie}

Treść artykułu dotyczy analizy materiału termoizolacyjnego systemu osłony termicznej, która związana jest $\mathrm{z}$ nagrzewaniem aerodynamicznym w trakcie wlotu pojazdu w atmosferę. Do analizy użyto przykładowego rozkładu strumienia ciepła w funkcji czasu lotu. Celem artykułu jest zbadanie wpływu na wyniki nowego materiału umieszczonego w modelu, mającego relatywnie wysoki współczynnik przewodności cieplnej w kierunku poprzecznym płytki izolacyjnej. Uważa się, że może on umożliwić wyrównanie temperatury na powierzchni konstrukcji podstawowej. Artykuł zawiera porównanie dwóch typów analizy termicznej wybranych modeli izolacyjnych płytek. W pierwszym przypadku założono, że modele zawierają tylko trzy warstwy, izolację, podkładkę i konstrukcję podstawową. W drugiej analizie obliczenia bazują na modelach zawierających cztery warstwy. Ze względu na dobre właściwości termiczne jako dodatkowy materiał wybrano stop tytanu. Wszystkie analizy uwzględniają dwa rodzaje modeli: płytki nieuszkodzone i uszkodzone. Wnioski zawierają wykresy rozkładu temperatur maksymalnych w funkcji czasu na powierzchniach wybranych warstw. Wyniki pozwoliły ustalić różnicę temperatur obliczonych na podstawie rozważonych przypadków.

Słowa kluczowe: nagrzewanie aerodynamiczne, niestacjonarny przepływ ciepła, osłona termiczna

DOI: $10.7862 / \mathrm{rm} .2014 .33$

Otrzymano/received: 25.05 .2014

Zaakceptowano/accepted: 28.06 .2014 